\title{
CD34 Identifies a Subset of Proliferating Microglial Cells Associated with Degenerating Motor Neurons in ALS
}

\author{
Mariángeles Kovacs ${ }^{1, \dagger}{ }^{\dagger}$, Emiliano Trias ${ }^{1,+}$, Valentina Varela ${ }^{1}$, Sofia Ibarburu ${ }^{1}$, \\ Joseph S. Beckman ${ }^{2}$, Ivan C. Moura 3,4,5,6,7,8, Olivier Hermine 3,4,5,6,7,8,9,10,11, \\ Peter H. King ${ }^{12,13} \mathbb{D}$, Ying Si ${ }^{12,13}$, Yuri Kwon ${ }^{12}$ and Luis Barbeito ${ }^{1, *(\mathbb{D}}$ \\ 1 Institut Pasteur de Montevideo, Montevideo 11400, Uruguay \\ 2 Linus Pauling Institute, Department of Biochemistry and Biophysics, Environmental Health Sciences Center, \\ Oregon State University, Corvallis, OR 97331, USA \\ 3 Imagine Institute, Hôpital Necker, 75015 Paris, France \\ 4 INSERM UMR 1163, Laboratory of Cellular and Molecular Mechanisms of Hematological Disorders and \\ Therapeutic Implications, 75015 Paris, France \\ 5 Paris Descartes-Sorbonne Paris Cité University, Imagine Institute, 75006 Paris, France \\ 6 CNRS ERL 8254, INSERM U1163, Université Paris Descartes, 75006 Paris, France \\ 7 Laboratory of Excellence GR-Ex, 75015 Paris, France \\ 8 Equipe Labélisée par la Ligue Nationale contre le cancer, 75013 Paris, France \\ 9 AB Science, 75008 Paris, France \\ 10 Department of Hematology, Hôpital Necker, 75015 Paris, France \\ 11 Centre national de référence des mastocytoses (CEREMAST), 75743 Paris, France \\ 12 Department of Neurology, University of Alabama at Birmingham, Birmingham, AL 35294, USA \\ 13 Birmingham Veterans Affairs Medical Center, Birmingham, AL 35294, USA \\ * Correspondence: barbeito@pasteur.edu.uy \\ + These authors contributed equally to this work.
}

Received: 31 May 2019; Accepted: 16 July 2019; Published: 9 August 2019

\begin{abstract}
Amyotrophic lateral sclerosis (ALS) is characterized by degeneration of upper and lower motor neurons accompanied by proliferation of reactive microglia in affected regions. However, it is unknown whether the hematopoietic marker CD34 can identify a subpopulation of proliferating microglial cells in the ALS degenerating spinal cord. Immunohistochemistry for CD34 and microglia markers was performed in lumbar spinal cords of ALS rats bearing the SOD1 ${ }^{\mathrm{G} 93 \mathrm{~A}}$ mutation and autopsied ALS and control human subjects. Characterization of CD34-positive cells was also performed in primary cell cultures of the rat spinal cords. CD34 was expressed in a large number of cells that closely interacted with degenerating lumbar spinal cord motor neurons in symptomatic SOD1 ${ }^{\mathrm{G} 93 \mathrm{~A}}$ rats, but not in controls. Most $\mathrm{CD} 34^{+}$cells co-expressed the myeloid marker CD11b, while only a subpopulation was stained for Iba1 or CD68. Notably, CD34 ${ }^{+}$cells actively proliferated and formed clusters adjacent to damaged motor neurons bearing misfolded SOD1. CD34 ${ }^{+}$cells were identified in the proximity of motor neurons in autopsied spinal cord from sporadic ALS subjects but not in controls. Cell culture of symptomatic SOD1 ${ }^{\mathrm{G} 93 \mathrm{~A}}$ rat spinal cords yielded a large number of CD34 ${ }^{+}$cells exclusively in the non-adherent phase, which generated microglia after successive passaging. A yet unrecognized CD34 ${ }^{+}$cells, expressing or not the microglial marker Iba1, proliferate and accumulate adjacent to degenerating spinal motor neurons, representing an intriguing cell target for approaching ALS pathogenesis and therapeutics.
\end{abstract}

Keywords: microglia; CD34; amyotrophic lateral sclerosis; misfolded SOD1; motor neurons 


\section{Introduction}

Neuroinflammation is a pathological hallmark of amyotrophic lateral sclerosis (ALS), causally associated with the progressive degeneration of upper and lower motor neurons [1,2]. At sites of motor neuron and axonal damage, reactive glial and infiltrating immune cells orchestrate a characteristic inflammatory microenvironment [3,4]. In particular, microglia display active proliferation and profound phenotypic changes in ALS subjects and ALS animal models $[5,6]$. A large body of evidence indicates that microglia play a crucial pathogenic role in accelerating motor neuron degeneration $[7,8]$. However, the complete understanding of different microglia cell phenotypes in ALS pathogenesis remains elusive.

In particular, the ALS rat model expressing the SOD1G93A mutation shows extensive microglia pathology concurrent with paralysis onset and progression [9-11], with extensive proliferation and development of aberrant or senescent phenotypes and formation of multinucleated giant cells $[10,12]$. Activated microglia bearing SOD1 mutations in rodents also exert toxicity to motor neurons [7] and contribute to accelerated progression of motor neuron disease in a non-cell autonomous manner [13]. In SOD1 ${ }^{\mathrm{G} 93 \mathrm{~A}}$ rats, microglia can transform into a distinct population of cells exhibiting an aberrant phenotype [9] and a potent neurotoxic effect on cultured motor neurons [14,15]. Notably, aberrant microglia are localized in the vicinity of spinal motor neurons after paralysis onset. Downregulation of aberrant glia through pharmacological inhibition of the receptor CSF-1R results in an extension of post-paralysis survival in rat and mouse models of ALS [16,17], suggesting their potential as drug targets to halt or slow disease progression. Given these facts, we aimed to identify different and as yet unknown microglia-related phenotypes that may also emerge and interact with degenerating motor neurons during disease progression in ALS.

CD34 is a transmembrane highly glycosylated protein, which has been extensively used as a marker of hematopoietic stem cells [18] and non-hematopoietic progenitor cells [19,20]. CD34 can regulate trafficking and migration of hematopoietic progenitor cells [20], which eventually may migrate to the CNS and differentiate into microglia [21]. Following CNS damage, CD34-expressing microglia have been found in affected regions [21-23], which are also characterized by microgliosis and blood-brain barrier damage. Because the identification of $\mathrm{CD} 34^{+}$cells in ALS remains elusive, we reasoned that this marker may allow the identification of a proliferating subset of microglia in the spinal cord of SOD1 ${ }^{\mathrm{G} 93 \mathrm{~A}}$ rats and autopsied ALS patients.

$\mathrm{SOD} 1^{\mathrm{G} 93 \mathrm{~A}}$ rats are characterized by the development of an adult-onset rapid progressing paralysis accompanied by dramatic microgliosis [9-11]. We took advantage of this particular SOD1 ${ }^{\text {G93A }}$ model to analyze CD34 expression along the course of paralysis progression. Here, we report a massive increase of cells expressing CD34 after paralysis onset, which proliferate and co-express myeloid markers. Notably, numerous CD34 ${ }^{+}$cells were associated with motor neurons in sporadic ALS and SOD1G93A rat spinal cords. In cell culture, $\mathrm{CD} 34^{+}$cells yielded microglia upon successive passages, suggesting that this marker identifies a population of proliferating microglia involved in ALS pathogenesis.

\section{Results}

\subsection{Increased Number and Proliferation of $C D 34^{+}$Cells in SOD1 ${ }^{\mathrm{G} 93 A}$ Rat Spinal Cord during Paralysis Progression}

First, we examined the expression of CD34 in the ventral horn of the lumbar cord at paralysis onset and $15 \mathrm{~d}$ of paralysis progression in $\mathrm{SOD} 1^{\mathrm{G} 93 \mathrm{~A}}$ rats as compared with non-transgenic rats, as shown in Figure 1A. Immunohistochemistry analysis revealed a progressive increase in CD34 expression in $\mathrm{SOD} 1^{\mathrm{G} 93 \mathrm{~A}}$ restricted to the ventral horn of the spinal cord, as shown in Figure 1A. CD34 immunoreactivity was significantly increased by 6 -fold and 14-fold at paralysis onset and 15d of paralysis progression, respectively, when compared to non-transgenic rats, as shown in Figure 1B. 


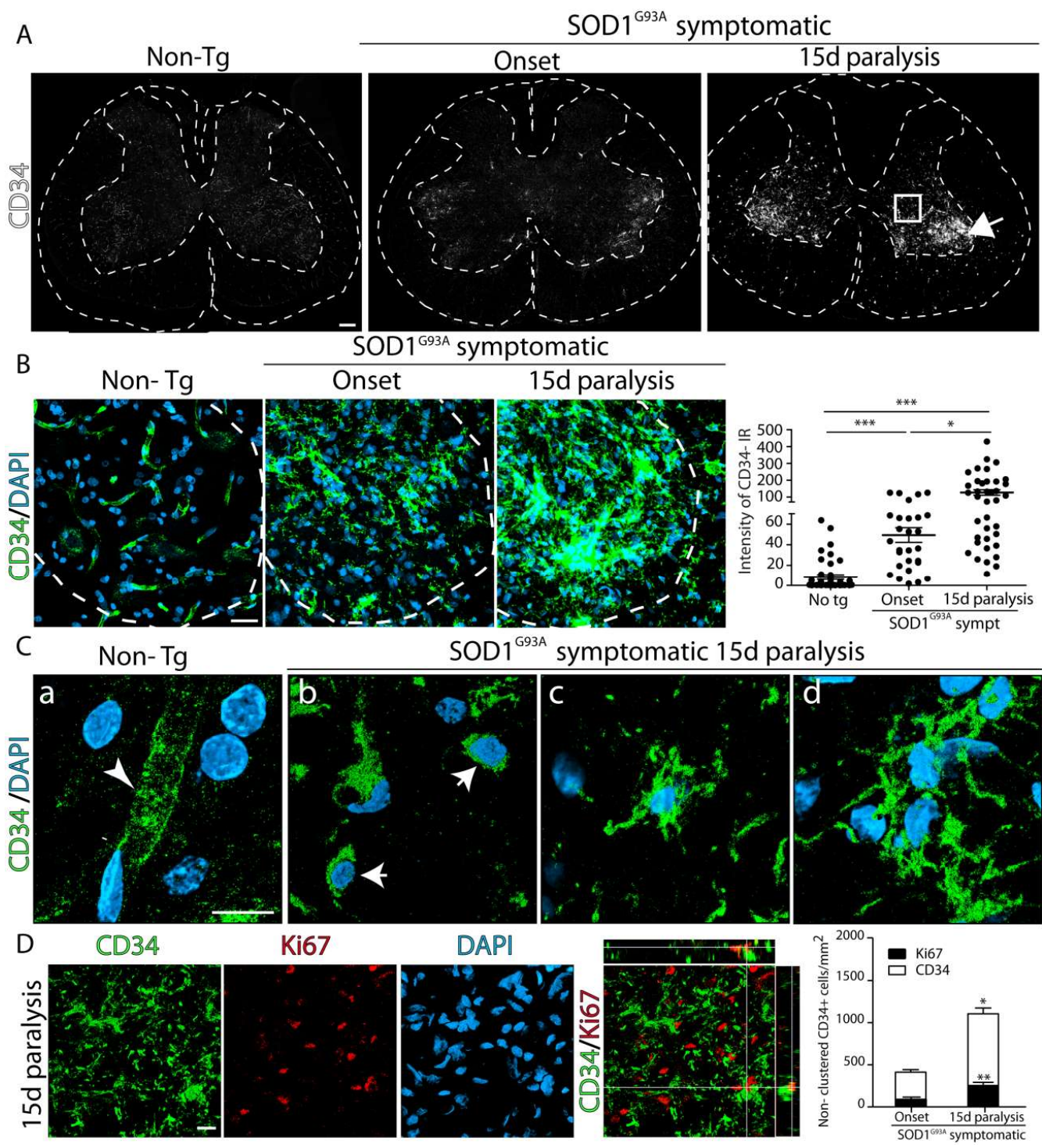

Figure 1. $\mathrm{CD} 34^{+}$immunoreactivity in the degenerating spinal cord during the course of paralysis in SOD1 ${ }^{\mathrm{G} 93 \mathrm{~A}}$ rats. Representative confocal microscopy images showing the expression of CD34 in the spinal cord of Non-transgenic (Non-Tg), SOD1 ${ }^{\mathrm{G} 93 \mathrm{~A}}$-onset, and SOD1 ${ }^{\mathrm{G} 93 \mathrm{~A}}-15 \mathrm{~d}$ paralysis rats. (A) Confocal tile reconstruction of the spinal cord showing increasing CD34 expression (white) in the ventral horn. The arrow and square indicate CD34 distribution in clustered and non-clustered cells, respectively. (B) Representative confocal images of CD34 expression (green) showing the detailed distribution of $\mathrm{CD}_{4} 4^{+}$cells in the ventral horn. Note CD34 staining in Non-Tg spinal cord was restricted to blood vessels while an increased immunoreactivity and different distribution was noted in SOD1 ${ }^{\mathrm{G} 93 \mathrm{~A}}$ rats. Dotted lines show the limit between grey and white matter in the lumbar cord. The graph to the right shows the quantitative analysis of CD34 immunoreactivity among groups. Quantitative data are expressed as mean \pm SEM; data were analyzed by Kruskal-Wallis followed by Dunn's multiple comparison test, ${ }^{*} p<0.05,{ }^{* * *} p<0.001$ was considered statistically significant (C) Representative confocal images showing the different $\mathrm{CD} 34^{+}$cell phenotypes present in non-clustered regions. a) Blood vessels in Non-Tg animals. b) Two round cells. c) Ramified cell. d) Small cluster of three cells. (D) Confocal images showing proliferating $\mathrm{CD}^{+} 4^{+}$cells in non-clustered regions stained with Ki67. Orthogonal view shows $\mathrm{Ki}^{+} 7^{+}$nuclei on the $\mathrm{CD} 34^{+}$cell. The graph to the right shows the quantitative analysis of non-vascular $\mathrm{CD} 34^{+}$and $\mathrm{CD} 34^{+} / \mathrm{Ki}^{+} 7^{+}$cells in non-clustered regions. Quantitative data are expressed as mean \pm SEM; data were analyzed by Mann-Whitney test, ${ }^{*} p<0.05$, ** $p<0.01$ was considered statistically significant. $n=4$ animals/condition. Scale bars: $100 \mu \mathrm{m}(\mathrm{A})$, $25 \mu \mathrm{m}(\mathbf{B})$, and $10 \mu \mathrm{m}(\mathbf{C}, \mathbf{D})$. 
In control non-transgenic rats, CD34 immunoreactivity of the lumbar spinal cord was restricted to capillaries, as shown in Figure 1B,C. In symptomatic SOD1 G93A rats, CD34 immunoreactivity displayed two morphological patterns: (i) clusters of $\mathrm{CD} 4^{+}$cells containing small, round cells packed together, as shown in Figure 1B, and (ii) non-clustered, isolated CD34 ${ }^{+}$cells displaying rounded or ramified morphology, as shown in Figure 1C. Quantitative analysis of non-clustered CD34 ${ }^{+}$cells in the ventral horn showed a significant number of cells at paralysis onset, increasing by 3-fold at advanced paralysis, as shown in Figure 1D. About 15\% of non-clustered CD34 ${ }^{+}$cells also displayed nuclear staining for the proliferation marker Ki67 at disease onset and advanced paralysis, suggesting a rapid expansion, as shown in Figure 1D.

\subsection{CD34+ Cells Co-Express Myeloid and Microglia Markers}

Figure $2 \mathrm{~A}$ shows that almost $80 \%$ of $\mathrm{CD} 34^{+}$cells in the ventral horn expressed the myeloid marker CD11b, while only $60 \%$ and $15 \%$ of cells expressed the microglia markers Iba1 or CD68, respectively, as shown in Figure 2B,C. In comparison, cells organized in large clusters mostly displayed staining for CD34 in the center and co-expressed CD11b or Iba1 in the periphery, as shown in Figure 2D, suggesting a center-periphery differentiation process.

\subsection{CD34 ${ }^{+}$Cells Progressively Invade Damaged Motor Neurons Accumulating Misfolded SOD1}

Figure 3 shows the early association between $\mathrm{CD} 34^{+}$cells and ventral horn motor neurons identified by Nissl or $\beta$ III-tubulin staining in SOD1 ${ }^{\mathrm{G} 93 \mathrm{~A}}$ rats. In non-transgenic rats, $\mathrm{CD} 34$ staining is restricted to blood vessels, while already in $\mathrm{SOD} 1{ }^{\mathrm{G} 93 \mathrm{~A}}$ symptomatic onset rats $\mathrm{CD} 34^{+}$cells begin to surround motor neurons, as shown in Supplementary Figure S1. Typically, CD34 ${ }^{+}$cells locate adjacent to damaged motor neuron cell bodies and proximal neurites, which could suggest a progressive pathogenic process for individual degenerating motor neurons.

As paralysis progressed, large motor neurons showed a tendency to lose Nissl staining and develop immunoreactivity for misfolded SOD1, indicative of dismantled endoplasmic reticulum and accumulation of misfolded proteins. Interestingly, motor neurons accumulating misfolded SOD1 were surrounded by a high number of proliferating CD $34^{+}$cells, as shown in Figure $4 \mathrm{~A}, \mathrm{~B}$, suggesting specific chemoattraction. However, as shown in Figure $4 \mathrm{Bc}$, some motor neuron accumulating misfolded SOD1 may have low numbers of $\mathrm{CD} 34^{+}$surrounding cells. Also, these $\mathrm{CD} 34^{+}$cells displayed nuclear staining for Ki67, as shown in Figure 4C, suggesting a site-specific expansion of CD34 ${ }^{+}$cells in the surroundings of degenerating motor neurons.

\subsection{Identification of CD34 ${ }^{+}$Cells in the Spinal Cord from Amyotrophic Lateral Sclerosis (ALS) Autopsied Subjects}

Next, we tested the hypothesis that CD34 ${ }^{+}$cells also accumulate in autopsied spinal cord from ALS subjects. Supplementary Table S1 shows the characteristics of five ALS and three control donors analyzed as well as the time of postmortem tissue processing. At the time of ALS diagnosis, there was electrophysiological evidence of leg muscle denervation in each patient, supporting the involvement of the lumbar spinal cord.

The histological analysis of lumbar spinal cord sections showed a systematic increase in CD34 ${ }^{+}$ cells in ALS subjects, respect to controls, where CD $34^{+}$immunostaining was restricted to capillaries close to motor neurons, as shown in Figure 5A,B. ALS specimens showed a decreased density of CD34 ${ }^{+}$ immunoreactivity in capillaries. Notably, a significant number of non-vascular CD34 ${ }^{+}$cells with round morphology were also identified in the spinal cord of ALS subjects but not in controls, with frequent $\mathrm{CD} 34^{+}$cells being localized in the proximity of apparent motor neuron cell bodies morphologically identified by typical shape, size, and localization in the ventral horn as described in other reports, and as shown in Figure 5C. CD $34^{+}$cells in ALS subjects were not grouped in clusters and only a subpopulation of $\mathrm{CD} 34^{+}$cells co-expressed Iba1, as shown in Figure 5D,E. 


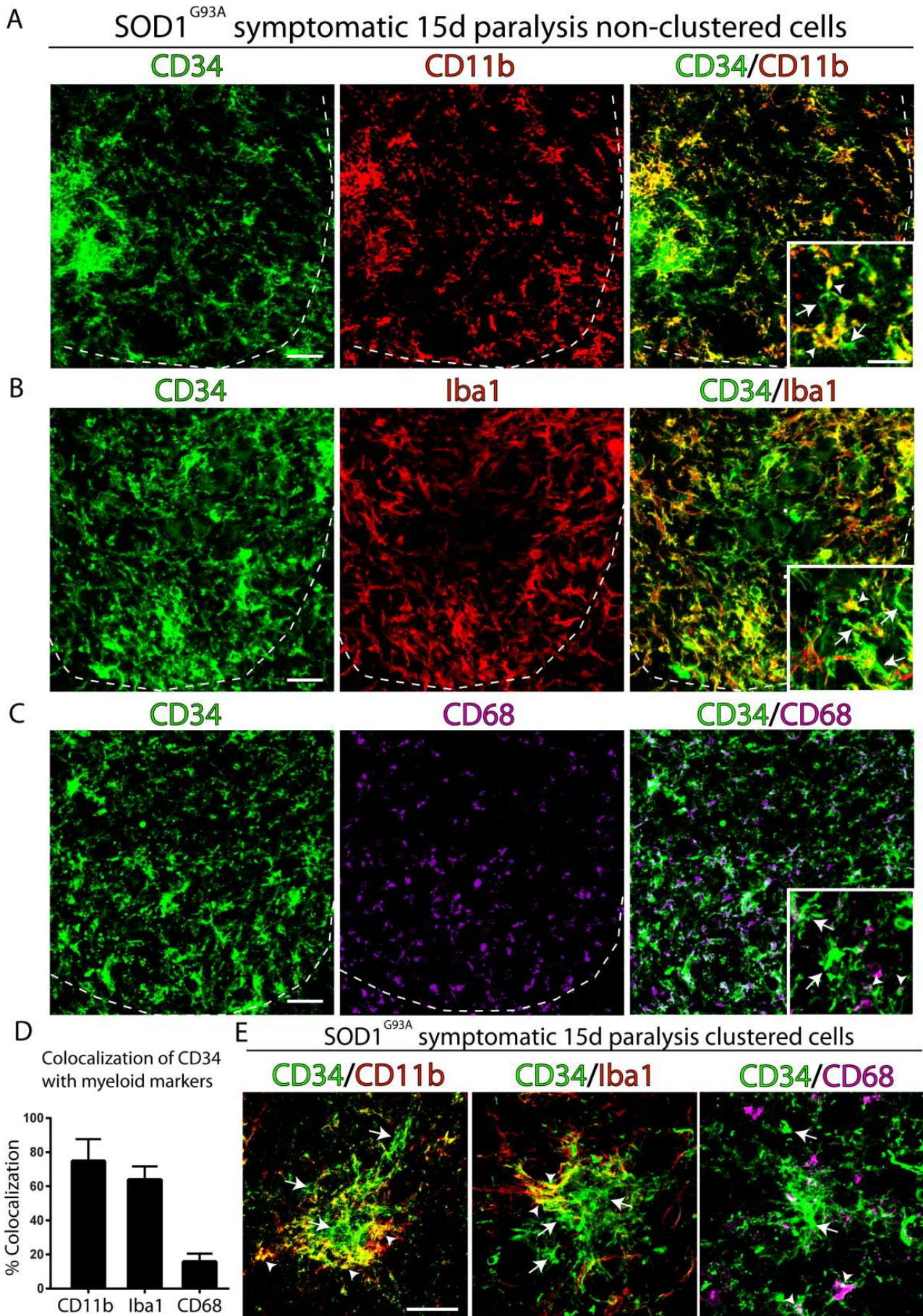

Figure 2. Co-expression of microglia markers and CD34. Representative confocal immunostaining of the ventral horn of symptomatic SOD1 ${ }^{\mathrm{G} 93 \mathrm{~A}}$ rat spinal cord showing the co-localization of myeloid/microglia markers CD11b (red, A), Iba1 (red, B), and CD68 (magenta, C). Insets show cell morphology and co-localization with CD34 at higher magnification. White arrows indicate CD34+ cells. White arrowheads indicate co-localization of CD34 with CD11b, Iba1, and CD68. Dotted lines show the limit between grey and white matter in the lumbar cord. (D) Confocal quantitative analysis of co-localization for CD34 and CD11b, Iba1, or CD68 in the ventral horn of symptomatic SOD1 ${ }^{\mathrm{G} 93 \mathrm{~A}}$ rat spinal cord. (E) Confocal analysis of the co-expression of CD34 and microglia markers in cell clusters observed in the degenerating spinal cord. Arrows indicate CD $34^{+}$cells in the cluster. Arrowheads indicate co-localization of CD34 with myeloid markers in the periphery of clusters. $n=4$ animals/condition. Scale bars: $25 \mu \mathrm{m}$ and $15 \mu \mathrm{m}$ in insets. 


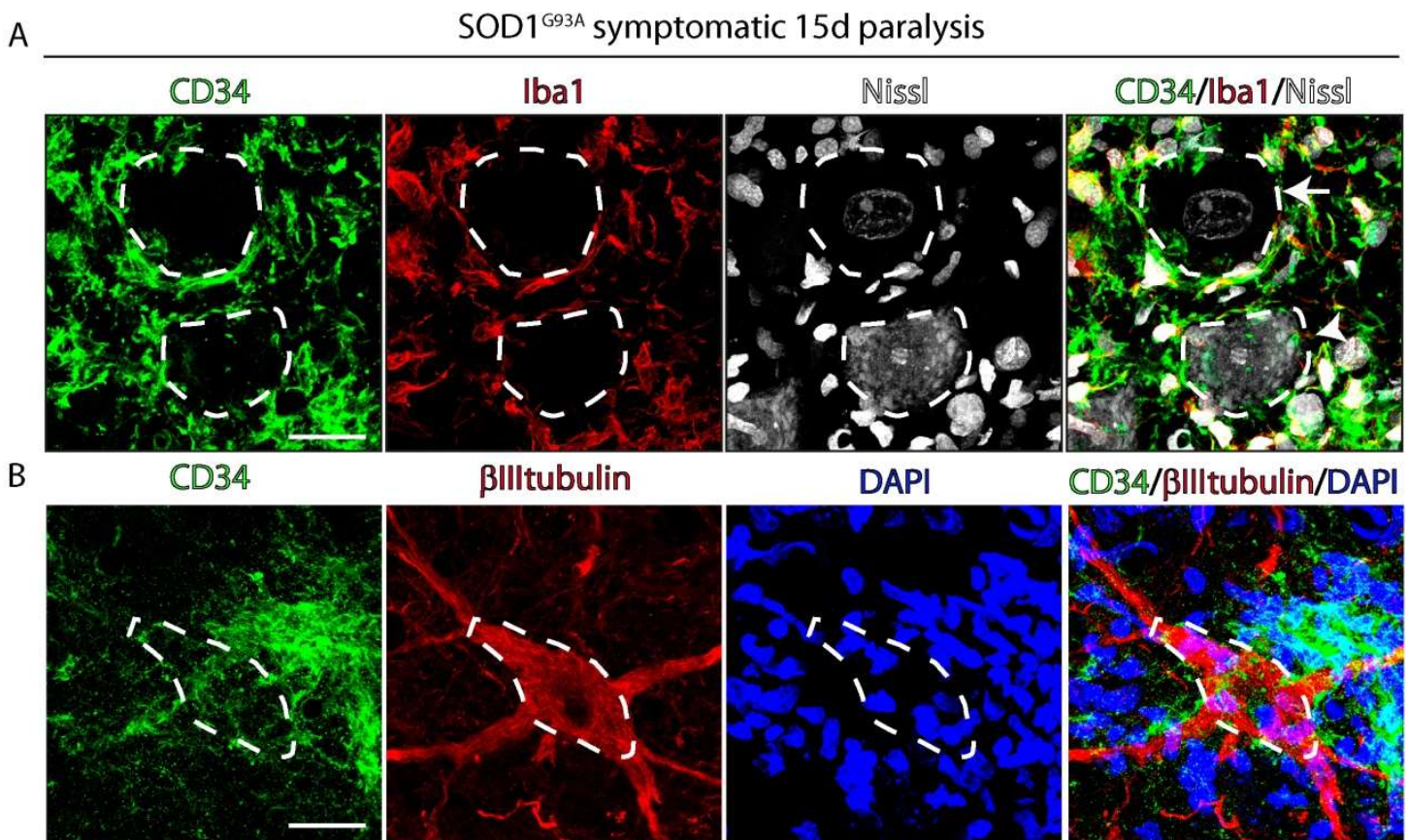

Figure 3. Spatial interaction of $\mathrm{CD} 34^{+}$cells with spinal motor neurons in symptomatic SOD1G93A rats. Confocal microphotograph analyzing the association of $\mathrm{CD} 34^{+}$cells with motor neurons (dotted white lines) stained with Nissl (A) and $\beta$ III-tubulin (B). Note that CD $34^{+} / \mathrm{Iba} 1^{+}$cells are adjacent to spinal motor neurons. Scale bars: $25 \mu \mathrm{m}$.

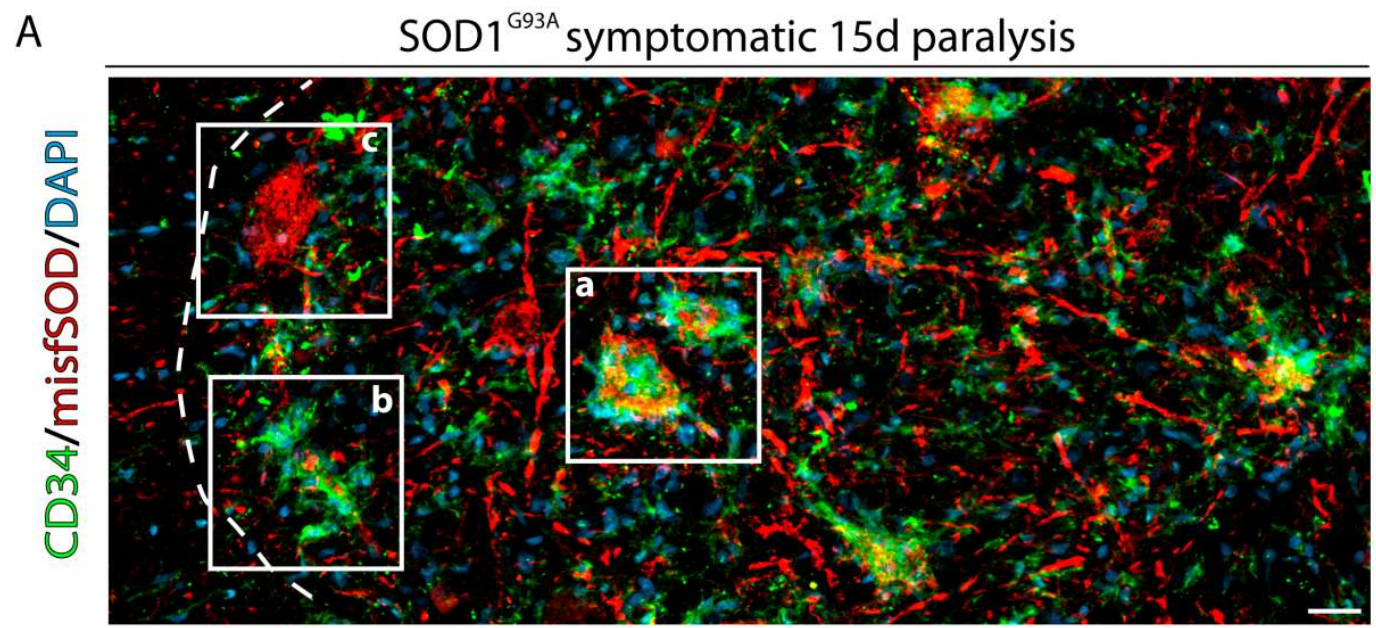

Figure 4. Cont. 


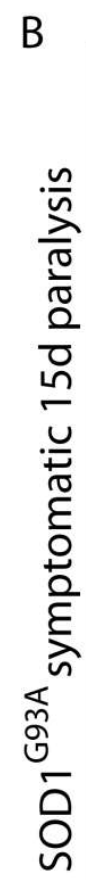

C
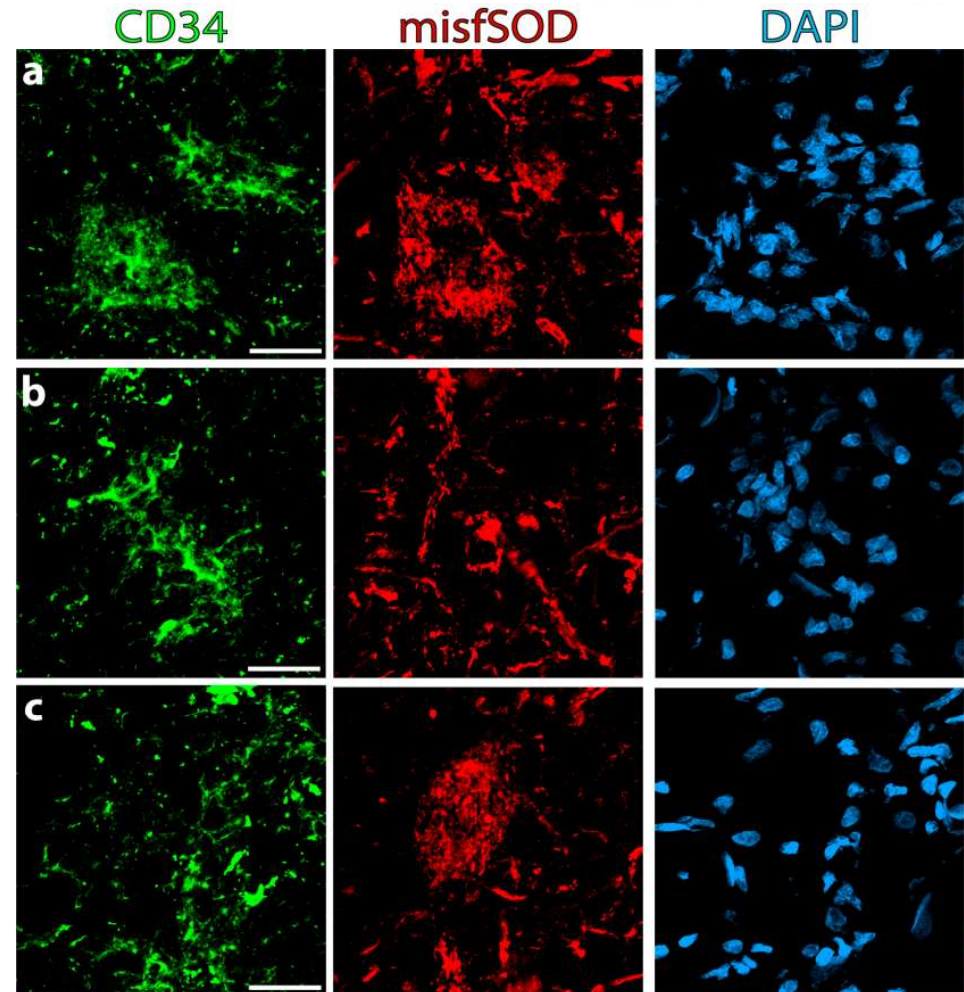

SOD1 ${ }^{\text {G93A }}$ symptomatic $15 \mathrm{~d}$ paralysis
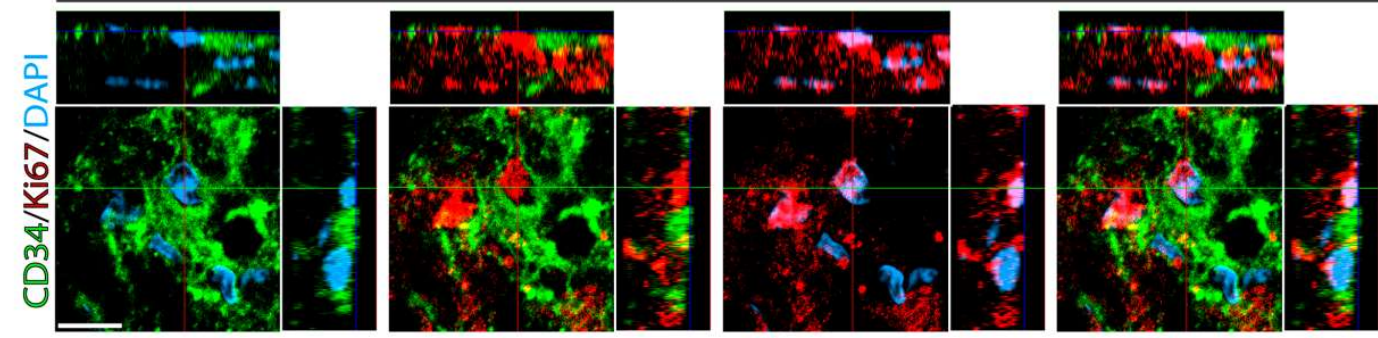

Figure 4. $\mathrm{CD}^{+}{ }^{+}$cells accumulate adjacent to motor neurons expressing misfolded SOD1. (A) Confocal tile reconstruction of the ventral horn showing $\mathrm{CD} 34^{+}$cell clusters adjacent to motor neurons expressing misfolded SOD1. CD $34^{+}$cells completely surround and attach to damaged motor neurons expressing misfolded forms of SOD1 and form compact clusters of cells, both around motor neuron somas (a) and processes $(\mathbf{b})$. Other motor neurons accumulating misfolded SOD1 have less CD34 ${ }^{+}$cells invading them (c). (B) Higher magnification analysis showing the clustering of $\mathrm{CD} 34^{+}$cells around motor neuron somas and processes. (C) Orthogonal view of the staining of proliferating CD34 ${ }^{+}$cell clusters expressing nuclear Ki67. Arrows indicate Ki67 ${ }^{+}$nuclei in a CD34 ${ }^{+}$cell cluster. Scale bars: $25 \mu \mathrm{m}(\mathbf{A}, \mathbf{B})$ and $10 \mu \mathrm{m}(\mathbf{C})$. 

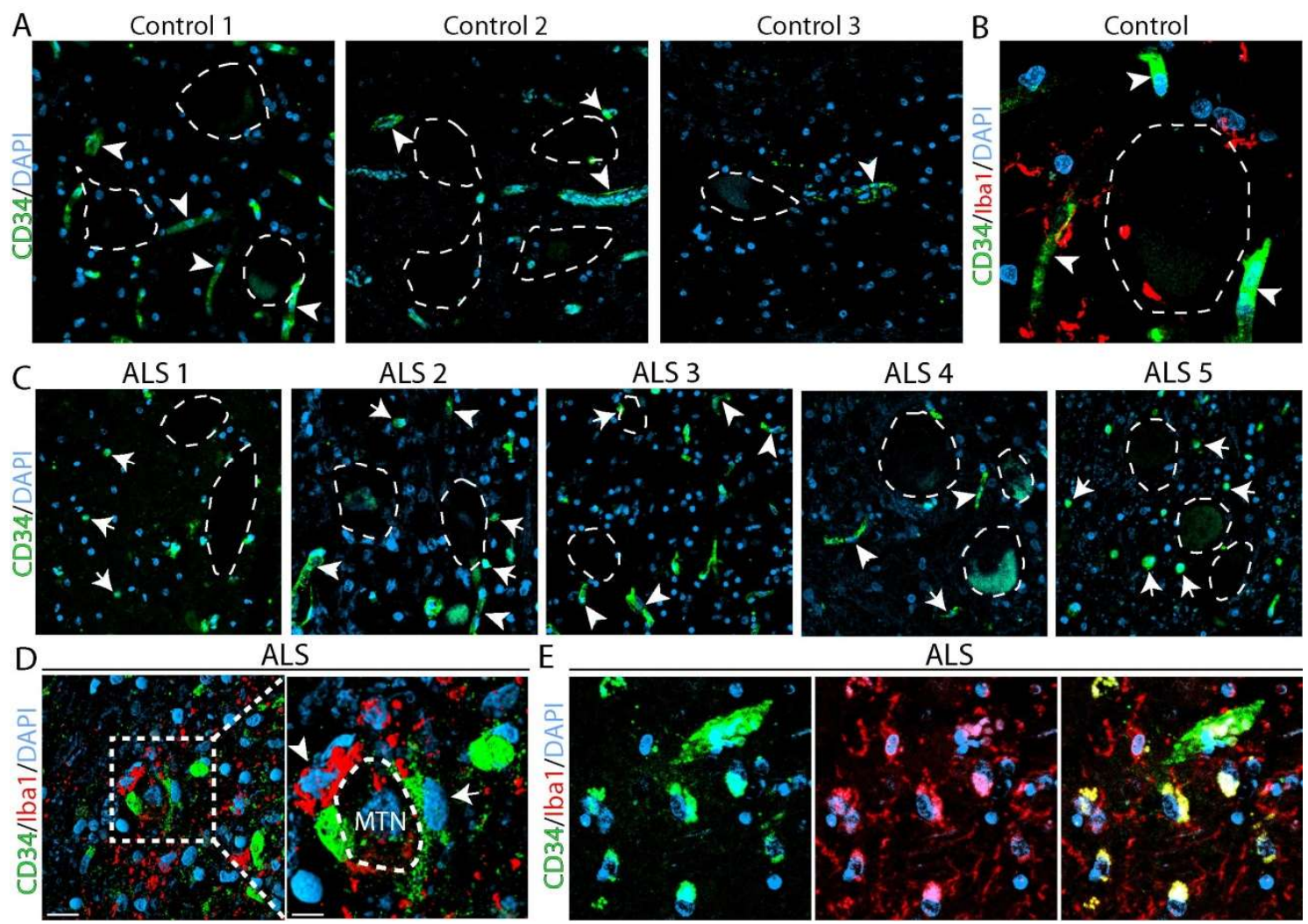

Figure 5. Identification of $\mathrm{CD}^{+} 4^{+}$cells in autopsied spinal cords from subjects with sporadic amyotrophic lateral sclerosis (ALS). Representative confocal microphotograph showing the occurrence of non-vascular CD34 ${ }^{+}$cells in sporadic ALS and control donors. (A-C) CD34 ${ }^{+}$cells (green) in controls and ALS subjects, respectively. Dotted lines delimitate the soma of spinal motor neurons. Note that in control subjects $\mathrm{CD} 34^{+}$cells were associated to blood vessels (arrowheads) with none or few rounded $\mathrm{CD}_{4}{ }^{+}$cells located adjacent to motor neurons. In comparison, in ALS donors numerous CD34 ${ }^{+}$cells with round morphology were located in the proximity to apparent motor neuron cell bodies (arrows). (D) Confocal image showing the coexistence of Iba1 $1^{+}$cells (red) that surround an apparent motor neuron cell body (dotted lines in right panel) with CD34 ${ }^{+}$cells in ALS specimens. Note non-vascular $\mathrm{CD}^{+}{ }^{+}$cells adjacent to motor neurons in ALS specimens but not in controls. (E) Co-expression of CD34 with Iba1 in myeloid cells at the ventral horn of the spinal cord of ALS patients. Scale bars: $25 \mu \mathrm{m}$ (A), $10 \mu \mathrm{m}$ (B), $50 \mu \mathrm{m}$ (C), $10 \mu \mathrm{m}$ (D), $20 \mu \mathrm{m}$ (E).

\subsection{Non-Adherent $C D 34^{+}$Cells Isolated from SOD ${ }^{G 93 A}$ Symptomatic Spinal Cord Give Rise to Microglia}

To determine the behavior of $\mathrm{CD} 34^{+}$cells, we isolated and cultured cells from symptomatic $\mathrm{SOD} 1^{\mathrm{G} 93 \mathrm{~A}}$ rat spinal cord. As previously reported [9], such cultures yield numerous adherent phagocytic microglia labeled with CD11b, CD68, and Iba1, as compared to only a few cells in non-transgenic controls. In the current study, CD34+ cells were not found in the adherent phase but accumulated in great number in the non-adherent phase, as shown in Figure 6A-D.

Cytological analysis of the non-adherent phase denoted that $\mathrm{CD} 34^{+}$cells organized in clusters of 10-20 cells, with CD34 ${ }^{+}$cores showing peripheral expression of CD11b, as shown in Figure 6B, suggesting a gradient of center-to-periphery differentiation. Approximately $35 \%$ of non-adherent cells displayed nuclear labeling with Ki67, indicative of active proliferation, as shown in Figure 6E.

When non-adherent cells from symptomatic SOD1 ${ }^{\mathrm{G} 93 \mathrm{~A}}$ rat spinal cords were subsequently passaged to another culture dish, numerous adherent and fully differentiated microglia were obtained in the adherent phase, as shown in Figure $6 \mathrm{C}, \mathrm{F}, \mathrm{G}$, suggesting their ability to further differentiate as a conventional vacuolated microglia which firmly attach to the plate. 

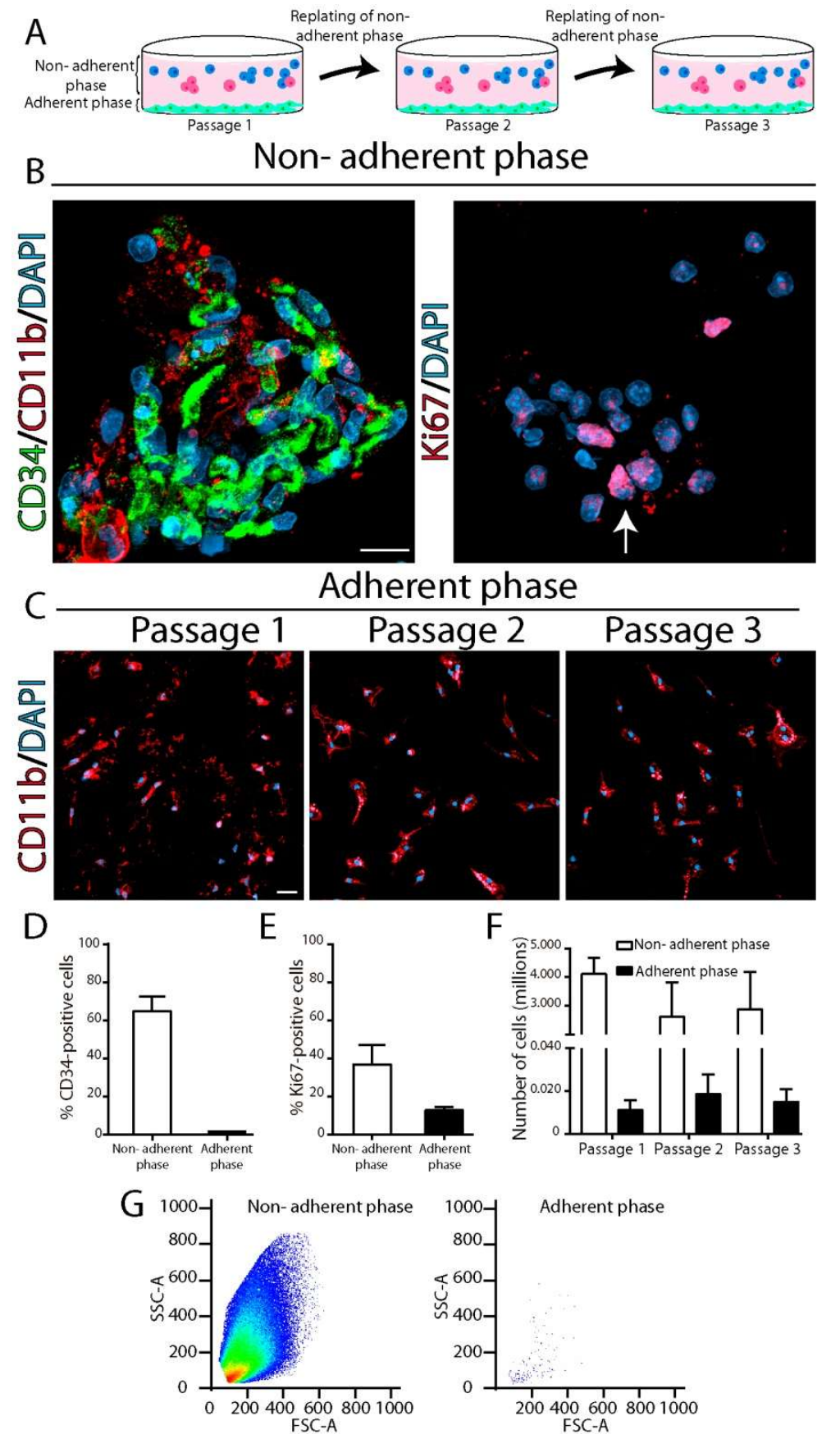

Figure 6. Characterization of $\mathrm{CD} 34^{+}$cells in primary spinal cord cultures from symptomatic SOD1G93A rats. Primary cultures were prepared from symptomatic rat's $(n=6)$ spinal cords and cells from the adherent and non-adherent phases were characterized. (A) Scheme showing the method used for analyzing the $\mathrm{CD}_{3} 4^{+}$and microglia cells (green attached cells) found in non-adherent cells (blue and red cells represent the heterogeneity of cultured non-adherent cells) after successive passages. (B) Cytological analysis of cell clusters found in the non-adherent phase showing CD34 ${ }^{+}$(green) and CD11 ${ }^{+}$(red, in left panel) cells as well as active proliferation as denoted by Ki67 nuclei staining (red, in right panel). (C) Immunostaining of adherent cells in successive passages showing sustained number of CD11b ${ }^{+}$cells (red). (D) Quantitative analysis showing CD34 ${ }^{+}$cells only in the non-adherent phase. (E) Quantitative analysis of $\mathrm{Ki}^{+} 7^{+}$cells in the non-adherent and adherent phase. (F) Quantitative analysis showing that cells accumulate in great number in the non-adherent phase and generate adherent $\mathrm{CD}_{11 \mathrm{~b}^{+}}$microglia in successive passages. (G) Representative plots of flow cytometry analysis showing the density of cells in both non-adherent and adherent phases. Scale bars: $10 \mu \mathrm{m}$ (B) and $25 \mu \mathrm{m}(\mathbf{C})$. 


\section{Discussion}

The present study characterizes a subpopulation of $\mathrm{CD} 34^{+}$cells that accumulate in the ventral horn of the ALS spinal cord during the symptomatic phase of the disease. This cell type has not been previously reported in ALS. Intriguingly, these cells seem to be attracted to damaged motor neurons in the spinal cord of SOD1 ${ }^{\mathrm{G} 93 \mathrm{~A}}$ rats and in autopsied spinal cords of ALS subjects. Evidence indicates that $\mathrm{CD} 34^{+}$cells behave as not fully differentiated proliferating microglia, most cells expressing the broad myeloid marker CD11b. In primary cell cultures of SOD1 ${ }^{\mathrm{G} 93 \mathrm{~A}}$ symptomatic spinal cord, CD34 ${ }^{+}$ cells are non-adherent and give rise to fully differentiated microglia, a behavior previously observed for microglia non-adherent precursor cells from the bone marrow [24]. Moreover, CD34 ${ }^{+}$cells exhibit an enormous proliferative capacity in $\mathrm{SOD} 1^{\mathrm{G} 93 \mathrm{~A}}$ rats forming clusters of many cells, suggesting a multi-clonal expansion process. Our findings in SOD1 ${ }^{\mathrm{G} 93 \mathrm{~A}}$ rats and sporadic ALS patients are in accordance with the analysis of a public database released by a spatial transcriptome study in SOD1G93A mice (https://als-st.nygenome.org/) [25], which shows a significant increase in CD34 transcripts in the lumbar spinal cord of mice over the course of the disease. Understanding the mechanism of controlling $\mathrm{CD} 34^{+}$precursors in ALS may have translational relevance in motor neuron diseases.

While previous reports have described the pathological features of reactive microglia and neuroinflammation in the spinal cords of ALS patients $[6,26,27]$, this is the first observation of the occurrence of $\mathrm{CD} 34^{+}$cells in sporadic ALS. The finding of $\mathrm{CD} 34^{+}$cells surrounding motor neurons was intriguing and clearly contrasted with control subjects, where CD34 was almost exclusively expressed in capillaries. However, the number of $\mathrm{CD} 34^{+}$cells among sporadic ALS subjects was much lower than in the SOD1 ${ }^{\mathrm{G} 93 \mathrm{~A}}$ rats and failed to form clusters, suggesting a lower rate of proliferation. Such differences might be related to the fact that the course of the disease in rat models develops in only few weeks as compared with months to years in subjects with ALS. Also, autopsied samples from terminally ill ALS patients might not be representative of active disease and motor neuron loss. Thus, $\mathrm{CD} 34^{+}$cells appear to be a novel and relevant cell type involved in the ALS cellular microenvironment. It would be interesting to assess whether CD34 transcripts or CD34 protein leak into the cerebrospinal fluid of ALS patients as potential biomarkers.

The present study has not addressed the question of whether CD34 ${ }^{+}$cells in the spinal cord of symptomatic SOD1 ${ }^{\mathrm{G} 93 \mathrm{~A}}$ rats originate from resident microglia, perivascular macrophages, or circulating hematopoietic stem cells, a subject that would require a detailed immunophenotyping analysis. In the absence of a major blood-brain barrier breakdown, microglia expansion has been attributed to proliferation and/or migration of resident microglia [28-31], which can exhibit an impressive proliferative capacity. Here, we found that most of the $\mathrm{CD} 34^{+}$cells co-expressed myeloid/microglial markers such as $\mathrm{CD} 11 \mathrm{~b}$ or Iba1, suggesting the vast majority of $\mathrm{CD}_{3} 4^{+}$cells correspond to a subpopulation of microglia. It is possible that a subset of proliferative microglia downregulate canonical myeloid markers to levels that escaped the immunodetection. In accordance, CD34 transcripts have been detected in microglia and brain endothelial cells during development [32], while the expression of CD34 proteins is upregulated following tissue injury or blood-brain barrier disruption [22,23]. Alternatively, CD34 ${ }^{+}$cells in ALS could originate from the influx and subsequent expansion of blood precursor cells. In support of this mechanism, previous studies have shown that bone marrow-derived myeloid progenitors are the source for microglia in different pathological conditions, such as ischemia [32,33], Experimental autoimmune encephalomyelitis [34], and CNS axonal damage [22,35]. In ALS models, blood myeloid cells can penetrate into the spinal cord and induce pathology [36] and CD34 ${ }^{+}$human bone marrow cells or CD34+ blood cord cells can engraft into spinal cord capillaries and parenchyma [37-40]. Thus, it will be important to determine the origin of CD34+ microglia and the mechanism controlling their proliferation.

The remarkable cluster proliferation of $\mathrm{CD} 4^{+}$cells adjacent to damaged motor neurons accumulating misfolded SOD1 is intriguing and has not been previously reported in ALS. Misfolded SOD1 is considered a pathological hallmark of ALS-affected motor neurons [41,42], not only in individuals carrying SOD1 mutations but also in sporadic ALS [43]. Here, we show evidence that 
accumulation of misfolded SOD1 in motor neurons may stimulate the focal proliferation and clustering of $\mathrm{CD} 34^{+}$cells. This effect may be partially explained by the ability of misfolded SOD1 to act as a damage-associated molecular pattern activating TLR receptors [44,45]. SOD1 ${ }^{\mathrm{G} 93 \mathrm{~A}}$ mice exhibit an improved hematopoiesis compared to mice expressing wild type SOD1, suggesting a specific effect of mutant SOD1 on hematopoietic progenitors [46]. In addition, other factors produced by motor neurons upon damage may potentially induce myeloid and microglial cell attraction and proliferation, including CSF1, MCP1, and ATP, among others [47-51]. It remains unknown whether damaged motor neurons in ALS express stromal cell-derived factor- $1 \alpha$ (SDF- $1 \alpha$ ), which is a potent chemokine and chemoattractant interacting with CD34 and CXCR4 in hematopoietic cells $[19,52,53]$.

In cell culture, blood myeloid precursors are non-adherent, and adherence to substrate is characteristic of differentiation into macrophages $[54,55]$. Here, we provide direct evidence that, in contrast to differentiated microglia which attach to the dish, $\mathrm{CD} 34^{+}$cells behave as immature myeloid cells remaining in the non-adherent phase, as previously described [24]. It remains to be elucidated whether adherent fully differentiated microglia originated from a subpopulation of non-adherent $\mathrm{CD} 11 \mathrm{~b}^{+}$cells. In addition, cultured $\mathrm{CD} 34^{+}$cells proliferated, formed clusters, and displayed the potential to differentiate into microglia after successive passages, as described for progenitor cells [24]. Further studies are needed to determine the stemness potential of $\mathrm{CD} 34^{+}$cells in the spinal cord.

In conclusion, the present study identifies $\mathrm{CD} 34^{+}$cells abnormally emerging in sporadic human ALS and SOD1 ${ }^{\mathrm{G} 93 \mathrm{~A}}$ rat spinal cords. Our findings broaden the myeloid/microglia phenotypic diversity in motor neuron disease. The accumulation of $\mathrm{CD} 34^{+}$microglia precursors around degenerating motor neurons harboring misfolded SOD1 deserves deeper mechanistic studies. CD34 ${ }^{+}$cells may represent a potential cell target for therapeutic development in ALS and other neurodegenerative diseases.

\section{Materials and Methods}

\subsection{Animals}

Male SOD1 ${ }^{\mathrm{G} 93 \mathrm{~A}}$ progeny, purchased from Taconic bioscience (NTac:SD-Tg(SOD1 $\left.{ }^{\mathrm{G} 93 \mathrm{~A}}\right) \mathrm{L} 26 \mathrm{H}$ ), were used for further breeding to maintain the line [11]. Rats were housed in a centralized animal facility with a $12 \mathrm{~h}$ light-dark cycle with ad libitum access to food and water. Perfusion with fixative was performed under $90 \%$ ketamine/10\% xylazine anesthesia and all efforts were made to minimize animal suffering, discomfort, or stress. All procedures using laboratory animals were performed in accordance with the national and international guidelines and were approved by the Institutional Animal Committee for animal experimentation. This study was carried out in strict accordance with the Institut Pasteur de Montevideo ethical committee's requirements (CEUA Approved protocol: \#005-17 to Dr. Luis Barbeito on $2^{\text {nd }}$ June 2017) and the national law ( $\mathrm{N}^{\circ}$ 18.611) for animal experimentation that follows the Guide for the Care and Use of Laboratory Animals of the National Institutes of Health (USA).

\subsection{Experimental Conditions}

At least 4 male rats were analyzed for the experimental condition. Non-transgenic (Non- $\mathrm{Tg}$ ) rats were 160-180 days old, transgenic SOD1 ${ }^{\mathrm{G} 93 \mathrm{~A}}$ rats developing hind limb paralysis were differentiated at the stage of disease onset (180-190 days old), and advanced paralysis (195-210 days old) defined as 15 days after disease onset.

\subsection{Determination of Disease Onset and End-Stage}

As described previously [56], all rats were weighed and evaluated for motor activity daily. Disease onset was determined for each animal when pronounced muscle atrophy was accompanied by an abnormal gait, typically expressed as subtle limping or dragging of one hind limb. When necessary, end-stage was defined by a lack of righting reflexes or the inability to reach food and water. 


\subsection{Human Tissue Collection}

The collection of post-mortem human ALS and control samples was approved by The University of Alabama at Birmingham (UAB) Institutional Review Board (Approved IRB Protocol: X091222037 to Dr. Peter H. King). All ALS patients were cared for at UAB and so detailed clinical records were available. Control samples were age-matched and were harvested from patients who expired from non-neurological causes. The average collection time after death was less than $10 \mathrm{~h}$. All tissues were collected by Peter H. King and Uing Si.

\subsection{Human Spinal Cord Immunohistochemistry}

In this study, $10 \mu \mathrm{m}$ spinal cord paraffin sections were sliced using a microtome. Following deparaffinization, slices were blocked and permeabilized in BSA 5\%/Triton X-100 0.5\% for $2 \mathrm{~h}$ at room temperature. Primary antibodies were incubated in BSA $1 \% /$ Triton X-100 $0.5 \%$ at $4{ }^{\circ} \mathrm{C}$ overnight. After washing, secondary antibodies were incubated for $3 \mathrm{~h}$ at room temperature. After PBS washing, Mowiol medium (Sigma, St. Louis, MO, USA) was used for mounting. Only ventral lumbar spinal cord sections were analyzed. Motor neuron somas were identified in the ventral spinal cord by typical morphology and nuclei. Saturated DAPI staining was used to better differentiate motor neuron somas as shown in Supplementary Figure S2.

\subsection{Immunohistochemistry of Spinal Cord}

Four percent paraformaldehyde fixed spinal cords were cryopreserved in 30\% sucrose (Sigma, St. Louis, MO, USA) at $4{ }^{\circ} \mathrm{C}$. After $72 \mathrm{~h}$, tissue was embedded in Tissue-Tek (Sakura), sectioned (longitudinal) using a cryostat, and collected on gelatin-coated slides. Then, $20 \mu \mathrm{m}$ sections were blocked for $2 \mathrm{~h}$ at room temperature in 5\% BSA, 0.3\% Triton X-100 in PBS, incubated with primary antibodies overnight at $4{ }^{\circ} \mathrm{C}$ in BSA $1 \% /$ Triton X-100 $0.3 \%$. After washing, secondary antibodies were incubated during $2 \mathrm{~h}$ at room temperature in BSA 1\%/Triton X-100 0.3\%. To determine primary antibodies' specificity, immunohistochemistry was carried out in the absence of primary antibodies. Non-significant immunofluorescence was detected with secondary antibodies incubation. DPX mounting medium (Sigma, St. Louis, MO, USA) was used for mounting. ImageJ software was used for analysis. For CD34 expression, cell density analysis was measured in the ventral horn of spinal cord images in at least 20 sections per spinal cord per animal $(n=4)$, as shown in Figure 1.

\subsection{Co-Expression Analysis of CD34 and Myeloid Markers}

The co-expression of CD34 with microglia markers Iba1, CD68, and CD11b was carried out using the maximum-intensity projections of images acquired from the ventral horn of spinal cord in at least 20 sections per spinal cord per animal among conditions $(n=4)$. The overlapped areas between CD34 and microglia markers were measured as previously described [57]. The number of Ki67 ${ }^{+}$cells co-expressing CD34 was determined by assessment on confocal $63 \times$ microphotographs of clearly identified CD34 ${ }^{+}$single cells in non-clustered $\mathrm{CD} 34^{+}$areas in at least 20 sections per spinal cord per animal among conditions $(n=4)$.

\section{8. $\mathrm{CD} 34^{+}$Cell Cultures from Symptomatic SOD $1^{\mathrm{G} 93 \mathrm{~A}}$ Rats}

$\mathrm{CD}_{3} 4^{+}$cells were obtained from a primary culture adult spinal cord of symptomatic SOD1 ${ }^{\mathrm{G} 93 \mathrm{~A}}$ rats according to the procedures described by Trias et al. (2013) [9] with minor modifications. Briefly, animals were euthanized by administering an overdose of ketamine/xylazine, and the spinal cord was dissected on ice. After the meninges were removed, the spinal cord was chopped finely and dissociated with $0.25 \%$ trypsin in a calcium-free buffer for $5 \mathrm{~min}$ at $37^{\circ} \mathrm{C}$. Trypsin treatment was stopped by adding DMEM/10\% (vol/vol) FBS in the presence of $50 \mu \mathrm{g} / \mathrm{mL}$ DNaseI and mechanical disaggregation by repeated pipetting. The resulting extract was passed through an $80 \mu \mathrm{m}$ mesh to eliminate tissue debris and was then spun. The pellet was resuspended in culture medium [DMEM/10\% (vol/vol) FBS, HEPES 
$(3.6 \mathrm{~g} / \mathrm{L})$, penicillin $(100 \mathrm{IU} / \mathrm{mL})$, and streptomycin $(100 \mu \mathrm{g} / \mathrm{mL})]$ and was then plated in glass-bottom p35 culture dishes for confocal microscopy or $25 \mathrm{~cm}^{2}$ tissue culture flasks for flow cytometry analysis. Culture medium was replaced every $48 \mathrm{~h}$. As described in Figure 6, the non-adherent phase of the culture was re-plated in new p35 dishes every $48 \mathrm{~h}$. Before plating every passage, adherent and non-adherent cells were quantified using a Neubauer hemocytometer. Non-adherent and adherent cells were characterized by immunocytochemistry as described below. To study the number of cells in the non-adherent and adherent phase of the primary cell culture from the adult spinal cord of symptomatic $\mathrm{SOD} 1^{\mathrm{G} 93 \mathrm{~A}}$ rats, after 2 days in vitro (DIV), both phases were analyzed by flow cytometry. Trypsin-EDTA, $0.05 \%$ (Thermo Fisher Scientific, Waltham, MA, USA) was used to remove adherent cells from the culture surface. Cells were analyzed using FlowJo software on an Attune NxT Flow Cytometer (Thermo Fisher Scientific, Waltham, MA, USA).

\subsection{Immunocytochemical Staining of Cultured Cells}

Cultured cells were fixed with $4 \%$ PFA for 20 min at $4{ }^{\circ} \mathrm{C}$ and then were washed three times with $10 \mathrm{mM}$ PBS (pH 7.4). Cells were permeabilized using 0.3\% Triton X-100 for $20 \mathrm{~min}$. Nonspecific binding was blocked by incubating fixed cells with 5\% BSA in PBS for $1 \mathrm{~h}$ at room temperature. Corresponding primary antibodies (see below) were diluted in blocking solution and incubated $3 \mathrm{~h}$ at room temperature. After washing, cells were incubated with secondary antibodies in blocking solution for $1 \mathrm{~h}$ at room temperature. DAPI was used for nuclei staining. At least 10 fields per plate were acquired in a confocal microscope for quantitative analysis using ImageJ software.

\subsection{Antibodies Used}

Primary antibodies used were: 1:200 rabbit monoclonal anti-CD34 (abcam, Cambridge, UK), 1:200 mouse monoclonal anti-CD34 (Thermo Fisher Scientific, Waltham, MA, USA), 1:300 mouse monoclonal anti-Iba1 (Millipore, Burlington, MA, USA), 1:200 mouse monoclonal CD68 (abcam, Cambridge, UK), 1:250 rat polyclonal anti-CD11b (BD Biosciences, Franklin Lakes, NJ, USA), 1:200 rabbit polyclonal anti-Ki67 (abcam, Cambridge, UK), 1:400 mouse monoclonal anti-GFAP (Sigma, St. Louis, MO, USA), 1:300 mouse monoclonal anti-S100 $\beta$ (Sigma, St. Louis, MO, USA), 1:300 mouse monoclonal anti-misfoldedSOD1 (MediMabs, Montreal, Northern Province, Canada), 1:400 mouse monoclonal anti- $\beta$ III-Tubulin (Millipore, Burlington, MA, USA). Secondary antibodies used were: 1:500 goat anti-rabbit-AlexaFluor546 or AlexaFluor633 (Thermo Fisher Scientific, Waltham, MA, USA), 1:500 goat anti-mouse-AlexaFluor488, AlexaFluor546, or AlexaFluor633 (Thermo Fisher Scientific, Waltham, MA, USA), 1:500 AlexaFluor633 (Thermo Fisher Scientific, Waltham, MA, USA).

\subsection{Fluorescence Imaging}

Fluorescence imaging was performed with a laser scanning Zeiss LSM 800 or LSM 880 confocal microscope with either a $25 \times$ (1.2 numerical aperture) objective or $63 \times(1.3$ numerical aperture) oil-immersion objective using Zeiss Zen Black/Blue software. Maximum intensity projections of optical sections were created with Zeiss Zen software (Carl Zeiss Microscopy GmbH, Jena, Germany).

\subsection{Statistics Analysis}

Quantitative data were expressed as mean \pm SEM. Two-tailed Mann-Whitney test or Kruskal-Wallis followed by Dunn's multiple comparison test were used for statistical analysis, with $p<0.05$ considered significant. GraphPad Prism 7.03 software (GraphPad Software, San Diego, CA, USA) was used for statistical analyses.

Supplementary Materials: Supplementary materials can be found at http://www.mdpi.com/1422-0067/20/16/3880/ s1. Table S1, Clinical characteristics of ALS and control subjects included in the study; Figure S1, Representative confocal microphotographs showing the association between CD34 and Nissl ${ }^{+}$motor neurons. Note that in Non-Tg animals, CD34 was restricted to blood vessels, while in the SOD1G93A symptomatic onset, CD34 is 
expressed in cells that start to surround motor neurons. Figure S2, Representative confocal microphotographs showing motor neuron identification in the ventral horn of the lumbar spinal cord in sections stained with DAPI.

Author Contributions: Formal analysis, M.K., E.T., and L.B.; Funding acquisition, E.T., J.S.B., and L.B.; Investigation, M.K., E.T., O.H., P.H.K., and L.B.; Methodology, M.K., E.T., V.V., S.I., P.H.K., Y.S., Y.K., and L.B; Validation, E.T. and L.B.; Writing-original draft, M.K., E.T., and L.B.; Writing-review and editing, M.K., E.T., J.S.B., I.C.M., O.H., P.H.K., and L.B.

Funding: This work was supported by Institut Pasteur de Montevideo-FOCEM Mercosur (COF 03/11), the Amyotrophic Lateral Sclerosis Association (00482), Agencia Nacional de Investigación e Innovación (ANII), Programa de Desarrollo de las Ciencias Básicas (PEDECIBA), Sistema Nacional de Investigadores (SNI), and the Comisión Sectorial de Investigación Científica (CSIC), Universidad de la República, Uruguay; Grupos I+D Program, \#1104.

Acknowledgments: We want to thank Tabaré de los Campos from the Microscopy Unit at Institut Pasteur de Montevideo for his assistance in imaging analysis. We also want to thank the staff from the Transgenic and Experimental Animal Unit from Institut Pasteur de Montevideo. We are grateful to our ALS patients who donated their skeletal muscle tissues post-mortem to advance ALS research.

Conflicts of Interest: Olivier Hermine is a cofounder and shareholder of AB science. Others have no conflict of interest.

\section{References}

1. Boillee, S.; Vande Velde, C.; Cleveland, D.W. ALS: A disease of motor neurons and their nonneuronal neighbors. Neuron 2006, 52, 39-59. [CrossRef]

2. Cleveland, D.W.; Rothstein, J.D. From Charcot to Lou Gehrig: Deciphering selective motor neuron death in ALS. Nat. Rev. Neurosci. 2001, 2, 806-819. [CrossRef]

3. Trias, E.; Ibarburu, S.; Barreto-Nunez, R.; Barbeito, L. Significance of aberrant glial cell phenotypes in pathophysiology of amyotrophic lateral sclerosis. Neurosci. Lett. 2017, 636, 27-31. [CrossRef]

4. Ilieva, H.; Polymenidou, M.; Cleveland, D.W. Non-cell autonomous toxicity in neurodegenerative disorders: ALS and beyond. J. Cell Biol. 2009, 187, 761-772. [CrossRef]

5. Corcia, P.; Tauber, C.; Vercoullie, J.; Arlicot, N.; Prunier, C.; Praline, J.; Nicolas, G.; Venel, Y.; Hommet, C.; Baulieu, J.L.; et al. Molecular imaging of microglial activation in amyotrophic lateral sclerosis. PLoS ONE 2012, 7, e52941. [CrossRef]

6. Henkel, J.S.; Beers, D.R.; Zhao, W.; Appel, S.H. Microglia in ALS: The good, the bad, and the resting. J. Neuroimmune Pharm. 2009, 4, 389-398. [CrossRef]

7. Liao, B.; Zhao, W.; Beers, D.R.; Henkel, J.S.; Appel, S.H. Transformation from a neuroprotective to a neurotoxic microglial phenotype in a mouse model of ALS. Exp. Neurol. 2012, 237, 147-152. [CrossRef]

8. Frakes, A.E.; Ferraiuolo, L.; Haidet-Phillips, A.M.; Schmelzer, L.; Braun, L.; Miranda, C.J.; Ladner, K.J.; Bevan, A.K.; Foust, K.D.; Godbout, J.P.; et al. Microglia induce motor neuron death via the classical NF-kappaB pathway in amyotrophic lateral sclerosis. Neuron 2014, 81, 1009-1023. [CrossRef]

9. Trias, E.; Diaz-Amarilla, P.; Olivera-Bravo, S.; Isasi, E.; Drechsel, D.A.; Lopez, N.; Bradford, C.S.; Ireton, K.E.; Beckman, J.S.; Barbeito, L. Phenotypic transition of microglia into astrocyte-like cells associated with disease onset in a model of inherited ALS. Front. Cell. Neurosci. 2013, 7, 274. [CrossRef]

10. Fendrick, S.E.; Xue, Q.S.; Streit, W.J. Formation of multinucleated giant cells and microglial degeneration in rats expressing a mutant $\mathrm{Cu} / \mathrm{Zn}$ superoxide dismutase gene. J. Neuroinflamm. 2007, 4, 9. [CrossRef]

11. Howland, D.S.; Liu, J.; She, Y.; Goad, B.; Maragakis, N.J.; Kim, B.; Erickson, J.; Kulik, J.; DeVito, L.; Psaltis, G.; et al. Focal loss of the glutamate transporter EAAT2 in a transgenic rat model of SOD1 mutant-mediated amyotrophic lateral sclerosis (ALS). Proc. Natl. Acad. Sci. USA 2002, 99, 1604-1609. [CrossRef]

12. Trias, E.; Beilby, P.R.; Kovacs, M.; Ibarburu, S.; Varela, V.; Barreto-Nunez, R.; Bradford, S.C.; Beckman, J.S.; Barbeito, L. Emergence of Microglia Bearing Senescence Markers During Paralysis Progression in a Rat Model of Inherited ALS. Front. Aging Neurosci. 2019, 11, 42. [CrossRef]

13. Boillee, S.; Yamanaka, K.; Lobsiger, C.S.; Copeland, N.G.; Jenkins, N.A.; Kassiotis, G.; Kollias, G.; Cleveland, D.W. Onset and progression in inherited ALS determined by motor neurons and microglia. Science 2006, 312, 1389-1392. [CrossRef]

14. Diaz-Amarilla, P.; Olivera-Bravo, S.; Trias, E.; Cragnolini, A.; Martinez-Palma, L.; Cassina, P.; Beckman, J.; Barbeito, L. Phenotypically aberrant astrocytes that promote motoneuron damage in a model of inherited amyotrophic lateral sclerosis. Proc. Natl. Acad. Sci. USA 2011, 108, 18126-18131. [CrossRef] 
15. Martinez-Palma, L.; Miquel, E.; Lagos-Rodriguez, V.; Barbeito, L.; Cassina, A.; Cassina, P. Mitochondrial Modulation by Dichloroacetate Reduces Toxicity of Aberrant Glial Cells and Gliosis in the SOD1G93A Rat Model of Amyotrophic Lateral Sclerosis. Neurotherapeutics 2019, 16, 203-215. [CrossRef]

16. Trias, E.; Ibarburu, S.; Barreto-Nunez, R.; Babdor, J.; Maciel, T.T.; Guillo, M.; Gros, L.; Dubreuil, P.; Diaz-Amarilla, P.; Cassina, P.; et al. Post-paralysis tyrosine kinase inhibition with masitinib abrogates neuroinflammation and slows disease progression in inherited amyotrophic lateral sclerosis. J. Neuroinflammation 2016, 13, 177. [CrossRef]

17. Martinez-Muriana, A.; Mancuso, R.; Francos-Quijorna, I.; Olmos-Alonso, A.; Osta, R.; Perry, V.H.; Navarro, X.; Gomez-Nicola, D.; Lopez-Vales, R. CSF1R blockade slows the progression of amyotrophic lateral sclerosis by reducing microgliosis and invasion of macrophages into peripheral nerves. Sci. Rep. 2016, 6, 25663. [CrossRef]

18. Krause, D.S.; Ito, T.; Fackler, M.J.; Smith, O.M.; Collector, M.I.; Sharkis, S.J.; May, W.S. Characterization of murine CD34, a marker for hematopoietic progenitor and stem cells. Blood 1994, 84, 691-701.

19. Sidney, L.E.; Branch, M.J.; Dunphy, S.E.; Dua, H.S.; Hopkinson, A. Concise review: Evidence for CD34 as a common marker for diverse progenitors. Stem Cells 2014, 32, 1380-1389. [CrossRef]

20. AbuSamra, D.B.; Aleisa, F.A.; Al-Amoodi, A.S.; Jalal Ahmed, H.M.; Chin, C.J.; Abuelela, A.F.; Bergam, P.; Sougrat, R.; Merzaban, J.S. Not just a marker: CD34 on human hematopoietic stem/progenitor cells dominates vascular selectin binding along with CD44. Blood Adv. 2017, 1, 2799-2816. [CrossRef]

21. Asheuer, M.; Pflumio, F.; Benhamida, S.; Dubart-Kupperschmitt, A.; Fouquet, F.; Imai, Y.; Aubourg, P.; Cartier, N. Human CD34+ cells differentiate into microglia and express recombinant therapeutic protein. Proc. Natl. Acad. Sci. USA 2004, 101, 3557-3562. [CrossRef]

22. Ladeby, R.; Wirenfeldt, M.; Dalmau, I.; Gregersen, R.; Garcia-Ovejero, D.; Babcock, A.; Owens, T.; Finsen, B. Proliferating resident microglia express the stem cell antigen CD34 in response to acute neural injury. Glia 2005, 50, 121-131. [CrossRef]

23. Graumann, U.; Ritz, M.F.; Rivero, B.G.; Hausmann, O. CD133 expressing pericytes and relationship to SDF-1 and CXCR4 in spinal cord injury. Curr. Neurovascular Res. 2010, 7, 144-154. [CrossRef]

24. Hinze, A.; Stolzing, A. Microglia differentiation using a culture system for the expansion of mice non-adherent bone marrow stem cells. J. Inflamm. 2012, 9, 12. [CrossRef]

25. Maniatis, S.; Aijo, T.; Vickovic, S.; Braine, C.; Kang, K.; Mollbrink, A.; Fagegaltier, D.; Andrusivova, Z.; Saarenpaa, S.; Saiz-Castro, G.; et al. Spatiotemporal dynamics of molecular pathology in amyotrophic lateral sclerosis. Science 2019, 364, 89-93. [CrossRef]

26. McGeer, P.L.; McGeer, E.G. Inflammatory processes in amyotrophic lateral sclerosis. Muscle Nerve 2002, 26, 459-470. [CrossRef]

27. Brettschneider, J.; Toledo, J.B.; Van Deerlin, V.M.; Elman, L.; McCluskey, L.; Lee, V.M.; Trojanowski, J.Q. Microglial activation correlates with disease progression and upper motor neuron clinical symptoms in amyotrophic lateral sclerosis. PLoS ONE 2012, 7, e39216. [CrossRef]

28. Fagan, A.M.; Gage, F.H. Mechanisms of sprouting in the adult central nervous system: Cellular responses in areas of terminal degeneration and reinnervation in the rat hippocampus. Neuroscience 1994, 58, 705-725. [CrossRef]

29. Ladeby, R.; Wirenfeldt, M.; Garcia-Ovejero, D.; Fenger, C.; Dissing-Olesen, L.; Dalmau, I.; Finsen, B. Microglial cell population dynamics in the injured adult central nervous system. Brain Res. Brain Res. Rev. 2005, 48, 196-206. [CrossRef]

30. Zhan, L.; Krabbe, G.; Du, F.; Jones, I.; Reichert, M.C.; Telpoukhovskaia, M.; Kodama, L.; Wang, C.; Cho, S.H.; Sayed, F.; et al. Proximal recolonization by self-renewing microglia re-establishes microglial homeostasis in the adult mouse brain. PLoS Biol. 2019, 17, e3000134. [CrossRef]

31. Streit, W.J.; Walter, S.A.; Pennell, N.A. Reactive microgliosis. Prog. Neurobiol. 1999, 57, 563-581. [CrossRef]

32. Schilling, M.; Besselmann, M.; Leonhard, C.; Mueller, M.; Ringelstein, E.B.; Kiefer, R. Microglial activation precedes and predominates over macrophage infiltration in transient focal cerebral ischemia: A study in green fluorescent protein transgenic bone marrow chimeric mice. Exp. Neurol. 2003, 183, 25-33. [CrossRef]

33. Tanaka, R.; Komine-Kobayashi, M.; Mochizuki, H.; Yamada, M.; Furuya, T.; Migita, M.; Shimada, T.; Mizuno, Y.; Urabe, T. Migration of enhanced green fluorescent protein expressing bone marrow-derived microglia/macrophage into the mouse brain following permanent focal ischemia. Neuroscience 2003, 117, 531-539. [CrossRef] 
34. Davoust, N.; Vuaillat, C.; Cavillon, G.; Domenget, C.; Hatterer, E.; Bernard, A.; Dumontel, C.; Jurdic, P.; Malcus, C.; Confavreux, C.; et al. Bone marrow CD34+/B220+ progenitors target the inflamed brain and display in vitro differentiation potential toward microglia. Faseb J. Off. Publ. Fed. Am. Soc. Exp. Biol. 2006, 20, 2081-2092. [CrossRef]

35. Dissing-Olesen, L.; Ladeby, R.; Nielsen, H.H.; Toft-Hansen, H.; Dalmau, I.; Finsen, B. Axonal lesion-induced microglial proliferation and microglial cluster formation in the mouse. Neuroscience 2007, 149, 112-122. [CrossRef]

36. Butovsky, O.; Siddiqui, S.; Gabriely, G.; Lanser, A.J.; Dake, B.; Murugaiyan, G.; Doykan, C.E.; Wu, P.M.; Gali, R.R.; Iyer, L.K.; et al. Modulating inflammatory monocytes with a unique microRNA gene signature ameliorates murine ALS. J. Clin. Investig. 2012, 122, 3063-3087. [CrossRef]

37. Garbuzova-Davis, S.; Haller, E.; Navarro, S.; Besong, T.E.; Boccio, K.J.; Hailu, S.; Khatib, M.; Sanberg, P.R.; Appel, S.H.; Borlongan, C.V. Transplantation of human bone marrow stem cells into symptomatic ALS mice enhances structural and functional blood-spinal cord barrier repair. Exp. Neurol. 2018, 310, 33-47. [CrossRef]

38. Garbuzova-Davis, S.; Willing, A.E.; Zigova, T.; Saporta, S.; Justen, E.B.; Lane, J.C.; Hudson, J.E.; Chen, N.; Davis, C.D.; Sanberg, P.R. Intravenous administration of human umbilical cord blood cells in a mouse model of amyotrophic lateral sclerosis: Distribution, migration, and differentiation. J. Hematother Stem Cell Res. 2003, 12, 255-270. [CrossRef]

39. Garbuzova-Davis, S.; Kurien, C.; Thomson, A.; Falco, D.; Ahmad, S.; Staffetti, J.; Steiner, G.; Abraham, S.; James, G.; Mahendrasah, A.; et al. Endothelial and Astrocytic Support by Human Bone Marrow Stem Cell Grafts into Symptomatic ALS Mice towards Blood-Spinal Cord Barrier Repair. Sci. Rep. 2017, 7, 884. [CrossRef]

40. Eve, D.J.; Steiner, G.; Mahendrasah, A.; Sanberg, P.R.; Kurien, C.; Thomson, A.; Borlongan, C.V.; Garbuzova-Davis, S. Reduction of microhemorrhages in the spinal cord of symptomatic ALS mice after intravenous human bone marrow stem cell transplantation accompanies repair of the blood-spinal cord barrier. Oncotarget 2018, 9, 10621-10634. [CrossRef]

41. Forsberg, K.; Graffmo, K.; Pakkenberg, B.; Weber, M.; Nielsen, M.; Marklund, S.; Brannstrom, T.; Andersen, P.M. Misfolded SOD1 inclusions in patients with mutations in C9orf72 and other ALS/FTD-associated genes. J. Neurol. Neurosurg. Psychiatry 2019, 90, 861-869. [CrossRef]

42. Forsberg, K.; Andersen, P.M.; Marklund, S.L.; Brannstrom, T. Glial nuclear aggregates of superoxide dismutase-1 are regularly present in patients with amyotrophic lateral sclerosis. Acta Neuropathol. 2011, 121, 623-634. [CrossRef]

43. Pare, B.; Lehmann, M.; Beaudin, M.; Nordstrom, U.; Saikali, S.; Julien, J.P.; Gilthorpe, J.D.; Marklund, S.L.; Cashman, N.R.; Andersen, P.M.; et al. Misfolded SOD1 pathology in sporadic Amyotrophic Lateral Sclerosis. Sci. Rep. 2018, 8, 14223. [CrossRef]

44. Gravel, M.; Beland, L.C.; Soucy, G.; Abdelhamid, E.; Rahimian, R.; Gravel, C.; Kriz, J. IL-10 Controls Early Microglial Phenotypes and Disease Onset in ALS Caused by Misfolded Superoxide Dismutase 1. J. Neurosci. 2016, 36, 1031-1048. [CrossRef]

45. Zhao, W.; Beers, D.R.; Henkel, J.S.; Zhang, W.; Urushitani, M.; Julien, J.P.; Appel, S.H. Extracellular mutant SOD1 induces microglial-mediated motoneuron injury. Glia 2010, 58, 231-243. [CrossRef]

46. Epperly, M.W.; Fisher, R.; Rigatti, L.; Watkins, S.; Zhang, X.; Hou, W.; Shields, D.; Franicola, D.; Bayir, H.; Wang, H.; et al. Amelioration of Amyotrophic Lateral Sclerosis in SOD1(G93A) Mice by M2 Microglia from Transplanted Marrow. Vivo 2019, 33, 675-688. [CrossRef]

47. Guan, Z.; Kuhn, J.A.; Wang, X.; Colquitt, B.; Solorzano, C.; Vaman, S.; Guan, A.K.; Evans-Reinsch, Z.; Braz, J.; Devor, M.; et al. Injured sensory neuron-derived CSF1 induces microglial proliferation and DAP12-dependent pain. Nat. Neurosci. 2016, 19, 94-101. [CrossRef]

48. White, F.A.; Sun, J.; Waters, S.M.; Ma, C.; Ren, D.; Ripsch, M.; Steflik, J.; Cortright, D.N.; Lamotte, R.H.; Miller, R.J. Excitatory monocyte chemoattractant protein-1 signaling is up-regulated in sensory neurons after chronic compression of the dorsal root ganglion. Proc. Natl. Acad. Sci. USA 2005, 102, 14092-14097. [CrossRef]

49. Kwon, M.J.; Shin, H.Y.; Cui, Y.; Kim, H.; Thi, A.H.; Choi, J.Y.; Kim, E.Y.; Hwang, D.H.; Kim, B.G. CCL2 Mediates Neuron-Macrophage Interactions to Drive Proregenerative Macrophage Activation Following Preconditioning Injury. J. Neurosci. 2015, 35, 15934-15947. [CrossRef] 
50. Szepesi, Z.; Manouchehrian, O.; Bachiller, S.; Deierborg, T. Bidirectional Microglia-Neuron Communication in Health and Disease. Front. Cell. Neurosci. 2018, 12, 323. [CrossRef]

51. Posfai, B.; Cserep, C.; Orsolits, B.; Denes, A. New Insights into Microglia-Neuron Interactions: A Neuron's Perspective. Neuroscience 2019, 405, 103-117. [CrossRef]

52. Bleul, C.C.; Fuhlbrigge, R.C.; Casasnovas, J.M.; Aiuti, A.; Springer, T.A. A highly efficacious lymphocyte chemoattractant, stromal cell-derived factor 1 (SDF-1). J. Exp. Med. 1996, 184, 1101-1109. [CrossRef]

53. Kucia, M.; Jankowski, K.; Reca, R.; Wysoczynski, M.; Bandura, L.; Allendorf, D.J.; Zhang, J.; Ratajczak, J.; Ratajczak, M.Z. CXCR4-SDF-1 signalling, locomotion, chemotaxis and adhesion. J. Mol. Histol. 2004, 35, 233-245. [CrossRef]

54. Klinder, A.; Markhoff, J.; Jonitz-Heincke, A.; Sterna, P.; Salamon, A.; Bader, R. Comparison of different cell culture plates for the enrichment of non-adherent human mononuclear cells. Exp. Med. 2019, 17, 2004-2012. [CrossRef]

55. Jobe, O.; Kim, J.; Tycksen, E.; Onkar, S.; Michael, N.L.; Alving, C.R.; Rao, M. Human Primary Macrophages Derived In Vitro from Circulating Monocytes Comprise Adherent and Non-Adherent Subsets with Differential Expression of Siglec-1 and CD4 and Permissiveness to HIV-1 Infection. Front. Immunol. 2017, 8, 1352. [CrossRef]

56. Trias, E.; King, P.H.; Si, Y.; Kwon, Y.; Varela, V.; Ibarburu, S.; Kovacs, M.; Moura, I.C.; Beckman, J.S.; Hermine, O.; et al. Mast cells and neutrophils mediate peripheral motor pathway degeneration in ALS. Jci Insight 2018, 3.

57. Tian, F.; Yang, W.; Mordes, D.A.; Wang, J.Y.; Salameh, J.S.; Mok, J.; Chew, J.; Sharma, A.; Leno-Duran, E.; Suzuki-Uematsu, S.; et al. Monitoring peripheral nerve degeneration in ALS by label-free stimulated Raman scattering imaging. Nat. Commun. 2016, 7, 13283. [CrossRef]

(C) 2019 by the authors. Licensee MDPI, Basel, Switzerland. This article is an open access article distributed under the terms and conditions of the Creative Commons Attribution (CC BY) license (http://creativecommons.org/licenses/by/4.0/). 